\title{
Animal Models in Cardiovascular Research: Hypertension and Atherosclerosis
}

\author{
Xin-Fang Leong, ${ }^{1,2}$ Chun-Yi Ng, ${ }^{1}$ and Kamsiah Jaarin ${ }^{1}$ \\ ${ }^{1}$ Department of Pharmacology, Universiti Kebangsaan Malaysia Medical Centre, Jalan Yaacob Latif, Bandar Tun Razak, \\ Cheras, 56000 Kuala Lumpur, Malaysia \\ ${ }^{2}$ Department of Clinical Oral Biology, Faculty of Dentistry, Universiti Kebangsaan Malaysia, Jalan Raja Muda Abdul Aziz, \\ 50300 Kuala Lumpur, Malaysia
}

Correspondence should be addressed to Kamsiah Jaarin; kamsiah@ukm.edu.my

Received 26 September 2014; Revised 17 December 2014; Accepted 14 January 2015

Academic Editor: Andrea Vecchione

Copyright (C) 2015 Xin-Fang Leong et al. This is an open access article distributed under the Creative Commons Attribution License, which permits unrestricted use, distribution, and reproduction in any medium, provided the original work is properly cited.

Hypertension and atherosclerosis are among the most common causes of mortality in both developed and developing countries. Experimental animal models of hypertension and atherosclerosis have become a valuable tool for providing information on etiology, pathophysiology, and complications of the disease and on the efficacy and mechanism of action of various drugs and compounds used in treatment. An animal model has been developed to study hypertension and atherosclerosis for several reasons. Compared to human models, an animal model is easily manageable, as compounding effects of dietary and environmental factors can be controlled. Blood vessels and cardiac tissue samples can be taken for detailed experimental and biomolecular examination. Choice of animal model is often determined by the research aim, as well as financial and technical factors. A thorough understanding of the animal models used and complete analysis must be validated so that the data can be extrapolated to humans. In conclusion, animal models for hypertension and atherosclerosis are invaluable in improving our understanding of cardiovascular disease and developing new pharmacological therapies.

\section{Introduction}

Research animals are valuable tools for understanding the pathophysiology and in developing therapeutic interventions for a disease. These animals are used in basic medical and veterinary research. Various animals have been reported as useful models in studying diseases afflicting humans and animals. Research animals include mice, rats, rabbits, guinea pigs, sheep, goats, cattle, pigs, primates, dogs, cats, birds, fish, and frogs [1]. Concerns have been raised concurrently with the rise of the use of animals over the years. This increase is mainly attributed to the use of genetically altered animals [1]. The similarities and differences between models must be taken into consideration for every project. Careful consideration should be given in choosing the most appropriate animal model to answer the specific research question of the study. With increasing awareness of animal welfare and research ethics, it is important to obtain accurate results using suitable models while reducing wastage of animals used for testing.
Animals are used in biomedical research for the following reasons.

(i) Feasibility. Animal models are relatively easy to manage, as compounding effects of dietary intake and environmental factors including temperature and lighting can be controlled. Therefore, there is relatively less environmental variation compared to human studies. Blood vessels and cardiac tissues can be isolated for detailed experimental and biomolecular investigations. Animals typically have a shorter life span than humans. Hence, they make good models, as they can be studied over their whole life cycle or even across several generations $[2,3]$.

(ii) Similarities to Human. Moreover, many animals are suitable due to their similarity in anatomical basis and physiological functions with humans. For example, chimpanzees and mice share about $99 \%$ and $98 \%$ of DNA with humans, respectively $[4,5]$. As a result, animals have the tendency 
to be affected by many health problems afflicting humans. Therefore, animals are good models for the study of human diseases.

(iii) Drug Safety. Preclinical toxicity testing, pharmacodynamics, and pharmacokinetics profile of drugs may be investigated on animals before the compounds or drugs are used in humans. This is vital, as prior to testing on humans, the effectiveness of a drug as potential treatment needs to be carried out on animals [6]. Interventions for diseases must be identified to eventually develop new medicines beneficial to humans and/or other animals. Drug safety profiles need to be determined in order to protect the animals, human, and environment. Harmful and detrimental effects of a drug need to be tested on a whole organism [6]. This can further ensure the dose to be employed in clinical trials, which do not cause fatality in the subsequent studies. The tested chemicals must also be safe for administration and avoid contaminating water, soil, and air. It is unethical to directly test drugs or chemicals on humans, thus warranting the need to use animals in the research, although this has been an issue debated by animal rights and welfare groups.

Before conducting research on animals, researchers must ensure that animals are essential for their experiments, with no viable alternatives. The use of 3 Rs principle relating to animal research has been a practice since first introduced by Russell and Burch in 1959 [7]. The 3Rs refer to replacement, reduction, and refinement. Replacement means conducting experiments using nonanimal models, such as in vitro method with cell culture as well as with computer model simulation (in silico), whenever possible. Nevertheless, the information obtained from in vitro is typically limited when compared to in vivo studies. Reduction refers to the need to reduce the number of animals, either from previous studies or by using calculation of size sample with a good experimental design. Refinement refers to efforts to minimize pain and suffering of test animals, taking into consideration animal handling and surgical procedures, housing environment and living conditions, and improvements in animal husbandry. These 3Rs are aimed at providing humane and scientifically improved research involving or avoiding the use of animal models [8]. Guidelines for reporting animal study are available to ensure the justification of using animals, such as the Animals in Research: Reporting In Vivo Experiments (ARRIVE) guidelines [9] and the Gold Standard Publication Checklist (GSPC) [10].

Even though animal studies have contributed much to our understanding of mechanisms of diseases, their value in predicting the effectiveness of treatment strategies in clinical trials has remained controversial [11-13]. Clinical trials are essential, as animal studies do not predict with sufficient certainty what will happen in humans. Hence, the findings from animal studies may not be deemed suitable for extrapolation to humans. A report by Williams et al. [11] suggested that a recurrent failure of interventions to translate the results obtained in animal studies to the clinical settings may be due to the ability to control genetic background in animal studies. Controlling the genetic background produces more consistent results. Additionally, it is possible that some of the genetic effects of the candidate loci are context-dependent. For example, the specific loci may play a significant role in sex (male versus female) or in age (young versus old) or in people of a specific body mass index or race $[12,13]$. Since these characteristics are not usually investigated or analyzed in many of the studies, there is a possibility that the failure to replicate is due to interactions between genes and environmental factors as well as to gene-gene interactions. If there are interactions between environmental risk factors and genotypes, the validity of extrapolation may become complicated [14].

Moreover, this failure may be explained in part by the methodological flaws in animal studies, eventually leading to a systematic bias which might generate incorrect conclusions about efficacy of a drug or a compound [11]. Per Bracken [15], reasons for the failure of animal experiments which may be translated into human trials include poor experimental design, execution, and analysis [16]. Systematic reviews provide information on whether animal studies are being properly carried out and published. However, systematic reviews are not able to resolve all queries regarding the applicability and relevance of animal studies to humans [13]. Selection biases affect how literature is selected and subsequently included in the systematic review, due to the criteria set by the different authors. The objectives of animal experiments are typically to discover new knowledge or make advances in understanding the diseases, instead of predicting the outcomes of human trials. Therefore, data obtained from animal studies may be unsuitable or too diverse for meaningful comparison with and prediction of the results of human trials. Nevertheless, systemic reviews ensure that all animal studies are published regardless of outcome, in order to avoid unnecessary duplication of expensive animal experiments [17]. Furthermore, systematic reviews may improve the quality and translational value of animal research to human trial [18].

\section{Animal Models for Hypertension}

Hypertension is one of the major risk factors for cardiovascular diseases. It has become a major public health issue in most developed and developing countries [19-21]. According to the Seventh Report of the Joint National Committee on Prevention, Detection, Evaluation and Treatment of High Blood Pressure, high blood pressure (BP) is defined as systolic blood pressure (SBP) greater than $140 \mathrm{mmHg}$ and/or diastolic blood pressure (DBP) greater than $90 \mathrm{mmHg}$ [22]. Patients with SBP ranging between $120 \mathrm{mmHg}$ and $139 \mathrm{mmHg}$, or DBP of $80 \mathrm{mmHg}$ to $89 \mathrm{mmHg}$, are categorized as prehypertensive. They have a higher risk of developing hypertension and therefore require medical intervention [22].

Human essential hypertension is a complex multifactorial disease which is influenced by genetic and environmental factors. Various models of experimental hypertension have been primarily developed to mimic hypertensive responses observed in humans [23]. These models are beneficial in the pharmacological screening of potential antihypertensive drugs, in addition allowing researchers to have a better understanding of the etiology, development, and progression 
of hypertension [24]. Since animal models of hypertension are a mimicry of human hypertension, many of these models have been developed using the etiological factors which have been hypothesized to have a contributory role in human hypertension, such as excessive salt intake, hyperactivity of renin-angiotensin-aldosterone system (RAAS), and genetic predisposition [24]. One animal model is insufficient for explaining the antihypertensive effects of a particular drug, because many pathways are involved in the development of BP dysregulation. In another word, several animal models are required to examine particular cardiovascular changes in an effective study [25]. Therefore, it is advisable that each of the studied models explains a unique pathway in the development of hypertension.

Several criteria need to be considered in order to develop an ideal animal model for hypertension. These factors include the feasibility and size of the animals, the reproducibility of the model, the ability to predict the potential antihypertensive properties of a drug, the similarity to human disease (mode of the disease: slow on-set versus acute), and economical, technical, and animal welfare considerations [23, 24]. In the past, dogs were mostly employed as a model to study hypertension. Currently, the preferred animal model is the rat. Along with rats, occasionally mice, monkeys, and pigs are also used as a model for experimental hypertension [26, 27]. These species have not been studied extensively for both practical and financial reasons. In 1963, Okamoto and Aoki introduced an experimental hypertension model without the involvement of physiological, pharmacological, or surgical intervention [28]. This model is known as the spontaneously hypertensive rat (SHR), which is the genetic strain of hypertensive rat. SHR has become the animal of choice for the screening of antihypertensive agents and the cornerstone of medical research in experimental hypertension [29].

Several forms of murine genetic models, including SHR, have become the focus of hypertensive research. The short life span, small size, and relatively low cost of the animals enable the researchers to study the natural history, genetic factors, and pathophysiological changes in hypertension [29]. Other strains have been developed, including the New Zealand strain [30], Milan strain [31], Dahl salt-sensitive strain [32], Sabra strain [33], and Lyon strain [34]. Essential hypertension is the most frequently encountered human type of hypertension. It is also known as primary hypertension, contributing to $95 \%$ of incidences. Essential hypertension is associated with genetic influences. Among the many strains of rat models SHR is generally used, even though it represents only a particular type of hypertension [35].

In addition to the genetic type of animal models, renovascular hypertension is a commonly employed model of hypertension. RAAS plays pivotal role in this form of hypertension $[36,37]$. In 1934, Goldblatt et al. developed a hypertension model through partial constriction of the renal artery in dog [38]. This has led to other renal-induced hypertension model using rats, rabbits, sheep, and cats [39]. When the renal artery is ligated or constricted, RAAS and the sympathetic nervous system are activated [40]. Renin is secreted by the kidneys when sympathetic activity is enhanced. Angiotensinogen is converted to angiotensin-I (Ang I) in the presence of renin.
Angiotensin-converting enzyme (ACE) plays a vital role in the regulation of $\mathrm{BP}$ via hydrolysis of the inactive form of Ang I to the active form, angiotensin II (Ang II). ACE is mainly located on the surface of the endothelium and epithelium involved in the constriction of blood vessels, subsequently leading to elevation of BP. Ang II is a potent vasoconstrictor and affects cardiovascular homeostasis. Apart from the role in vasoconstriction, Ang II also stimulates the release of aldosterone, further increasing blood volume and BP due to water and salt retention [41].

Nitric oxide (NO) has been demonstrated to be a potent vasodilator, and its release from the endothelium may be triggered by vasoactive substances such as acetylcholine (ACh) [42]. The endothelium preserves its integrity through endothelium-relaxing dependent factor, which is the best to be characterized as NO [43]. Therefore, NO plays an important role in the regulation of $\mathrm{BP}$ [44]. The production of NO is catalyzed by nitric oxide synthase (NOS). Deficiency of NOS has led to a reduction in NO synthesis $[45,46]$. Impaired NO bioavailability will result in reduced endothelium-dependent vasorelaxation, eventually leading to hypertension. This NOdeficient model can be induced by oral administration of $\mathrm{N}^{\omega}$-nitro-L-arginine methyl ester (L-NAME) up to eight weeks, resulting in a significant rise in both SBP and DBP, renal and hepatic markers, and inflammatory parameters in male Wistar rats [47]. Often, BP is elevated after four weeks of L-NAME treatment. Long-term administration of NOS inhibitors, such as L-NAME, provides a new form of hypertension with target organ damage. Studies have reported that L-NAME-induced hypertension has been associated with attenuated endothelium-dependent relaxations, cardiac and aortic tissue damage, renal vascular, and glomerular fibrosis [48-50]. Since the etiology of hypertension is different among the various animal models, it is imperative to make a rational choice for a specific model (Table 1). The choice will significantly affect the outcome of the study.

Soriguer et al. [51] conducted a study on cooking oils, reporting that repeatedly oxidized frying oil is an independent risk factor for hypertension. Hence, hypertension is related to the degradation of the dietary frying oil. Previously, adult male Sprague-Dawley rats aged 3 months were administered with $15 \%$ weight/weight (w/w) of repeatedly heated vegetable oils for 16 weeks [52] or 24 weeks [53-56]. Chronic consumption of heated oil diets causes an increase in BP. The BP-raising effect of the heated vegetable oils may be attributable to the diminished endothelium-dependent relaxation responses. Heated oil diet promotes oxidative stress, resulting in NO sequestration and inactivation. Furthermore, heated oil causes a significant increase in ACE activity and a reduction in heme oxygenase content. The thermal oxidation of vegetable oils promotes the generation of free radicals and may contribute to the pathogenesis of hypertension in rats. This heated oil-induced hypertension model employed male instead of female rats. Female hormones have been shown to have cardioprotective properties $[57,58]$. BP was measured using the conventional heating tail-cuff method. Even though invasive methods such as carotid arterial cannulation may provide more accurate readings, these may cause injury in the animals and further complicated the experiment. In addition, 
TABLE 1: Common animal models for hypertension with different etiology.

\begin{tabular}{|c|c|}
\hline Experimental model & Description \\
\hline $\begin{array}{l}\text { Genetic hypertension } \\
\text { (i) SHR } \\
\text { (ii) Dahl salt-sensitive } \\
\text { (iii) Transgenic }\end{array}$ & $\begin{array}{l}\text { (i) SHR is developed by inbreeding Wistar rats (brother-to-sister) with the highest BP [28]. The BP } \\
\text { increases at week } 4 \text { to week } 6 \text { and reach systolic BP of } 180-200 \mathrm{mmHg} \text { [28]. SHR may develop cardiac } \\
\text { hypertrophy, cardiac failure, renal dysfunction, and impaired endothelium-dependent relaxations [60-62]. } \\
\text { (ii) Dahl salt-sensitive rats derived from Sprague-Dawley rats on the basis of administering high NaCl diet. } \\
\text { Salt-sensitive rats become hypertensive when given normal salt diets; however these rats develop severe } \\
\text { and fatal hypertension with high salt diet ( } 8 \% \mathrm{NaCl} \text { ) [32]. These rats may develop cardiac hypertrophy, } \\
\text { severe cardiac failure, hypertensive nephropathy, impaired endothelium-dependent relaxations [63-65]. } \\
\text { (iii) Transgenic model can be generated by overexpression of a specific gene, for example, the mouse } \\
\text { Ren-2 gene, and TGR(mREN2)27 [66]. Manifestations include marked cardiac hypertrophy, moderate } \\
\text { proteinuria, and impaired endothelium-dependent relaxations [67,68]. }\end{array}$ \\
\hline Endocrine hypertension & $\begin{array}{l}\text { (i) Administration of DOCA in a combination with high salt diet and unilateral nephrectomy [69]. } \\
\text { (ii) DOCA-induced hypertension induces a low renin model of hypertension [70]. } \\
\text { (iii) Increased cardiac weight, proteinuria, glomerulosclerosis, and impaired endothelium-dependent } \\
\text { relaxations [71,72]. }\end{array}$ \\
\hline $\begin{array}{l}\text { Environmental } \\
\text { hypertension }\end{array}$ & $\begin{array}{l}\text { (i) Stress-induced hypertension using flashing lights, loud noise, restraint cage, and cold or hot stimuli } \\
{[73,74] \text {. }} \\
\text { (ii) Activation of sympathetic nervous system and RAAS may contribute to the initiation of stress-induced } \\
\text { hypertension }[75,76] \text {. }\end{array}$ \\
\hline $\begin{array}{l}\text { Pharmacological } \\
\text { hypertension }\end{array}$ & $\begin{array}{l}\text { (i) Nitric oxide-deficient model by administering NOS inhibitors such as L-NAME }[77] . \\
\text { (ii) Increase in BP was reported during long-term oral treatment with NOS inhibitors }[78,79] . \\
\text { (iii) Development of endothelial dysfunction is gradually with increased of BP }[80] .\end{array}$ \\
\hline Renal hypertension & $\begin{array}{l}\text { (i) This includes two-kidney one-clip hypertension ( } 2 \mathrm{~K} 1 \mathrm{C} \text {; constriction of one renal artery while the } \\
\text { contralateral kidney is left intact), one-kidney one-clip hypertension (1K1C; one renal artery is constricted } \\
\text { and the contralateral kidney is removed), and two-kidney two-clip hypertension ( } 2 \mathrm{~K} 2 \mathrm{C} \text {; constriction of } \\
\text { aorta or both renal arteries) [81, 82]. } \\
\text { (ii) In the two-kidney model, circulating renin and aldosterone levels are increased [83], which are most } \\
\text { notably in the early phase of hypertension [84]. }\end{array}$ \\
\hline
\end{tabular}

SHR: spontaneously hypertensive rat; BP: blood pressure; NaCl: sodium chloride; TGR: transgenic rat; RAAS: renin-angiotensin-aldosterone system; DOCA: deoxycorticosterone acetate; NOS: nitric oxide synthase; L-NAME: $\mathrm{N}^{\omega}$-nitro-L-arginine methyl ester.

these studies were performed to compare and monitor the effects of heated oil diets among the experimental groups up to 24 weeks using large number of rats. Thus, the noninvasive tail-cuff method is more suitable for measuring BP for longterm studies [59].

\section{Animal Models for Atherosclerosis}

Atherosclerosis, or "hardening of the arteries", is a chronic inflammatory disease characterized by endothelial dysfunction and disorganization of intimal architecture owing to the accumulation of lipid deposits, inflammatory cells and cell debris in the intima of elastic, and medium to large muscular arteries. It underlies many of the common causes of cardiovascular deaths, including stroke and heart attack [85]. Several modifiable (including advanced age, gender, and heredity) and nonmodifiable risk factors (including dyslipidemia, hypertension, sedentary lifestyle, tobacco smoking, and diabetes mellitus) have been identified for the development of atherosclerosis [86]. Many clinical and experimental attempts have been performed to understand the pathophysiology of the disease. Amongst them, animals have been used for more than a century to study atherosclerosis. The first evidence that experimental atherosclerosis could be induced in animals came into view as early as 1908 by Ignatowski, who demonstrated atherogenesis in the aortic wall of rabbits fed a diet enriched in animal proteins including meat, eggs, and milk [87]. Since then, numerous animal models have been used for understanding the mechanisms involved in both induction and regression of atherosclerotic lesions [88, 89]. Rats, rabbits, dogs, pigs, and monkeys are well-established animal models for atherosclerosis, and thrombosis. Nonhuman primates, hamster, mouse, cat, and guinea pig have also been used, but with lesser extent [90].

Several studies documented a significant relationship between elevated levels of serum cholesterol and development of atherosclerotic plaques in experimental animals. High-fat diets such as the $1 \%$ or $2 \%$ cholesterol diet have been found to elevate serum low-density lipoprotein (LDL), inducing atherogenesis in certain animals such as hamsters [91] and guinea pigs [92]. Therefore, the use of high-fat diets in promoting atherosclerosis in animal models has been a valuable tool for studying pathogenesis, as well as for testing potential therapies in reversing the atherosclerotic process.

Overall, an ideal animal model should be representative of the human atherosclerosis and should be feasible and affordable. Although animal models have played a significant role in our understanding of induction of atherosclerotic lesions, they have some limitations (Table 2). Not all experimental animals, such as rats and mice, respond similarly to a given high-fat diet, due to inherent genetic differences. Rats and mice are not good models for atherosclerosis, because 
TABle 2: Advantages and disadvantages of common animal models for atherosclerosis.

\begin{tabular}{|c|c|c|}
\hline Animal & Advantages & Disadvantages \\
\hline Rats and mice & $\begin{array}{l}\text { (i) Low cost } \\
\text { (ii) High availability } \\
\text { (iii) Easy to handle and maintain } \\
\text { (iv) Manageable breeding } \\
\text { (v) Well-established genomic sequencing permit } \\
\text { genetic manipulation }\end{array}$ & $\begin{array}{l}\text { (i) Typically resistant to atherogenesis } \\
\text { (ii) Absence of plasma CETP activity [93] } \\
\text { (iii) Most cholesterol is transported through HDL } \\
\text { particles [94] } \\
\text { (iv) The small size of mice limits frequent blood } \\
\text { sampling and dissection of small arteries }\end{array}$ \\
\hline Rabbits & $\begin{array}{l}\text { (i) Easy to handle and maintain } \\
\text { (ii) Relatively inexpensive } \\
\text { (iii) High availability } \\
\text { (iv) Sensitive to dietary cholesterol induction of } \\
\text { atherosclerosis } \\
\text { (v) Large enough to permit physiological experiments }\end{array}$ & $\begin{array}{l}\text { (i) Lesion location less compared with humans [95] } \\
\text { (ii) Deficiency in hepatic lipase leads to hepatotoxicity } \\
\text { following prolonged cholesterol feeding [96] }\end{array}$ \\
\hline Pigs & $\begin{array}{l}\text { (i) An anatomically and physiologically similar } \\
\text { cardiovascular system compared to humans [97] } \\
\text { (ii) Susceptible to spontaneous atherosclerosis [98] } \\
\text { (iii) Comparable patterns of plaque distribution [99] } \\
\text { (iv) High availability (for miniature pigs) }\end{array}$ & $\begin{array}{l}\text { (i) Large size with resultant management difficulties } \\
\text { (ii) High maintenance cost }\end{array}$ \\
\hline Dogs & $\begin{array}{l}\text { (i) Easy to work with } \\
\text { (ii) Ideal size } \\
\text { (iii) High availability }\end{array}$ & $\begin{array}{l}\text { (i) Highly resistant to atherogenesis } \\
\text { (ii) Status and anthropomorphic attitudes toward dogs } \\
\text { (iii) Differences in important aspects of their } \\
\text { cardiovascular system than humans [100] }\end{array}$ \\
\hline Hamsters & $\begin{array}{l}\text { (i) Low cost } \\
\text { (ii) High availability } \\
\text { (iii) Easy to handle and maintain } \\
\text { (iv) Carry a significant portion of its plasma cholesterol } \\
\text { in LDL particles and is therefore close to humans [101] } \\
\text { (v) Sensitive to high-fat diets [102] }\end{array}$ & $\begin{array}{l}\text { (i) Inconsistency of lesion development and absence of } \\
\text { advanced lesions [103] } \\
\text { (ii) Require highly abnormal diets and/or treatment } \\
\text { with a cytotoxic chemical agent, such as streptozotocin } \\
\text { [104] }\end{array}$ \\
\hline Guinea pigs & $\begin{array}{l}\text { (i) Develop diet-induced atherosclerosis } \\
\text { (ii) Most of cholesterol is transported in LDL particles } \\
\text { [105] } \\
\text { (iii) Ovariectomized guinea pigs showed a similar } \\
\text { plasma lipid profile as in postmenopausal women [106] }\end{array}$ & $\begin{array}{l}\text { (i) Require constant supplementation with vitamin C, } \\
\text { which potentially acts as an antioxidant to interfere } \\
\text { with atherogenesis [107] }\end{array}$ \\
\hline Nonhuman primates & $\begin{array}{l}\text { (i) Genetically resemblance to humans } \\
\text { (ii) Similar omnivorous diet } \\
\text { (iii) Similar metabolism } \\
\text { (iv) Develop metabolic syndrome as they age [108] }\end{array}$ & $\begin{array}{l}\text { (i) Expensive } \\
\text { (ii) Low availability } \\
\text { (iii) Live long (thus requiring lengthy experimental } \\
\text { periods) } \\
\text { (iv) Potential carriers of dangerous viral zoonoses [104] } \\
\text { (v) Significant ethical issues }\end{array}$ \\
\hline Pigeon & $\begin{array}{l}\text { (i) Low cost } \\
\text { (ii) Easy handling } \\
\text { (iii) Susceptible to atherosclerosis } \\
\text { (iv) Sufficient size }\end{array}$ & $\begin{array}{l}\text { (i) Nonmammalian } \\
\text { (ii) Lipoprotein compositions and metabolism are } \\
\text { different [109] } \\
\text { (iii) Differences in arterial histology [110] }\end{array}$ \\
\hline Chicken & $\begin{array}{l}\text { (i) Low cost } \\
\text { (ii) High availability } \\
\text { (iii) Develop atherosclerosis naturally in aorta and } \\
\text { coronary arteries, with cholesterol feeding accelerating } \\
\text { the pathogenesis [111] }\end{array}$ & $\begin{array}{l}\text { (i) Nonmammalian } \\
\text { (ii) Viral infection is associated with atherosclerosis } \\
{[112,113]}\end{array}$ \\
\hline
\end{tabular}

CETP: cholesterol ester transfer protein; HDL: high-density lipoprotein; LDL: low-density lipoprotein.

they are typically resistant to atherogenesis, and even diets as high as $10 \% \mathrm{w} / \mathrm{w}$ cholesterol are not usually sufficient to produce vascular lesions [121]. The lipid metabolism of a normal rat and a mouse is primarily based on high-density lipoprotein (HDL) rather than on LDL as in humans, which might be attributable to resistance to atherogenesis [122]. The use of other interventions, such as vitamin $\mathrm{D}_{3}$, to establish atherosclerotic calcification or aortic medical calcification, is often required [123]. Furthermore, a high-fat diet may represent a toxic proinflammatory stimulus rather than a low and chronic inflammatory state to animals [124]. Moreover, from a nutritional perspective, the dilution of a chow diet with lipids may increase the caloric density of the diet and reduce the ratio of essential nutrients to dietary energy, potentially leading to an imbalance in nutrient intake in animals consuming the atherogenic diet [125]. 
TABLE 3: Genetically modified animal models for atherosclerosis.

\begin{tabular}{|c|c|}
\hline Experimental model & Description \\
\hline $\begin{array}{l}\text { Apolipoprotein E knockout } \\
\left(\text { ApoE }^{-I-}\right) \text { mice }\end{array}$ & $\begin{array}{l}\text { Apolipoprotein } \mathrm{E} \text { (apoE), a constituent of lipoprotein responsible for packaging cholesterol and } \\
\text { other fats and carrying them through the bloodstream, is inactivated by gene targeting. They exhibit } \\
\text { a higher total plasma cholesterol concentration of } 11 \mathrm{mM} \text { compared to } 2 \mathrm{mM} \text { in their parent C57BL/6 } \\
\text { mice [114]. }\end{array}$ \\
\hline $\begin{array}{l}\text { LDL receptor knockout } \\
\left(\mathrm{LDLR}^{-/-}\right) \text {mice }\end{array}$ & $\begin{array}{l}\text { LDL receptor (LDLR) is a cell surface receptor in liver cells that mediates the endocytosis of apoE to } \\
\text { clear cholesterol-abundant LDL particles from the circulation. Total plasma cholesterol levels } \\
\text { increase twofold compared to those of wild-type, owing to a seven- to ninefold increase in } \\
\text { intermediate density lipoproteins (IDL) and LDL without a significant change in HDL [115]. }\end{array}$ \\
\hline $\begin{array}{l}\text { Scavenger receptor class B } \\
\text { member } 1 \text { knockout (SR-BI } \\
\text { KO) mice }\end{array}$ & $\begin{array}{l}\text { Scavenger receptor class B member } 1 \text { (SR-BI) functions in facilitating the uptake of cholesterol from } \\
\text { HDL in the liver. It plays a key role in determining the levels of plasma cholesterol (primarily HDL). } \\
\text { Heterozygous and homozygous mutants show } 31 \% \text { and } 125 \% \text { increase, respectively, in plasma } \\
\text { cholesterol concentrations than wild-types [116]. }\end{array}$ \\
\hline$d b / d b$ mice & $\begin{array}{l}\text { OB-R is a high affinity receptor for leptin, an important circulating signal for the regulation of } \\
\text { feeding, appetite, and body weight. Fatty acid oxidation rates are progressively higher in } d b / d b \text { mice } \\
\text { in parallel with the earlier onset and greater duration of hyperglycemia [117]. }\end{array}$ \\
\hline$o b / o b$ mice & $\begin{array}{l}\text { A mutation results in a structurally defective leptin that does not bind to the OB-R. Mice that are } \\
o b / o b \text { have no leptin action and exhibit obesity and endothelial dysfunction [118]. }\end{array}$ \\
\hline Fatty Zucker rats & $\begin{array}{l}\text { A spontaneous mutant gene ( } f a \text { or fatty) that affects the action of the leptin. They have high levels of } \\
\text { lipids and cholesterol in their bloodstream and become noticeably obese by } 3 \text { to } 5 \text { weeks of age and } \\
\text { over } 40 \% \text { lipid of their body composition by } 14 \text { weeks of age [119]. }\end{array}$ \\
\hline $\begin{array}{l}\text { Cholesterol ester transfer } \\
\text { protein (CETP) } \\
\text { transgenic rats }\end{array}$ & $\begin{array}{l}\text { CETP inhibits HDL-mediated reverse cholesterol transport by transferring cholesterol from HDL to } \\
\text { very low-density lipoprotein (VLDL) and LDL, promoting atherogenesis. The animals exhibit } 82 \% \\
\text { increase in non-HDL cholesterol in addition to } 80 \% \text { reduction in HDL cholesterol when compared } \\
\text { to wild-type rats [120]. }\end{array}$ \\
\hline
\end{tabular}

HDL: high-density lipoprotein; LDL: low-density lipoprotein.

A small, genetically reproducible, murine model of atherosclerosis has been long desired due to projections of relatively easy handling and breeding procedures as well as its low cost. Researchers have used genetic technology to produce a number of genetically modified murine models to overcome the many deficiencies of larger animals, particularly to allow studies of potential therapies that require large numbers of subjects. An exciting scientific breakthrough occurred in 1992, when Zhang et al. found that ApoEdeficient mice generated by gene targeting had five times higher plasma cholesterol level and developed foam cell-rich depositions in their proximal aortas by the age of 3 months [114]. This model was the very first line of genetically modified murine model for atherosclerosis studies introduced to the research community. Since then, further research has led to other genetically modified models that mimic important aspects of atherosclerosis, such as fatty streaks, deposition of foam cells, vulnerable and stable plaques, and related complications such as arterial calcification, ulceration, hemorrhage, plaque rapture, thrombosis, and stenosis. Fatty Zucker rats, cholesterol ester transfer protein (CETP) transgenic rats, LDL receptor-knockout (KO) mice, and $d b / d b$ mice are a few of the genetically modified models developed over recent years (Table 3). The development of techniques for direct genetic modification that have been previously restricted to murine species is promising to produce other new strains.

According to the oxidation hypothesis of atherosclerosis [126], oxidized LDL (oxLDL) plays a key role in the initiation of the atherosclerotic lesion as well as in almost every step of the atherogenic process, from the formation of cholesterol-laden foam cells in plaques to the functioning as chemoattractants for macrophages and vascular smooth muscle cells $[126,127]$. Since the etiology of atherosclerosis is multifactorial, the potential lipid-raising effect and lipid oxidation might contribute to atherogenesis together. The potential atherogenic effect of heated oils has been studied in experimental animals. Staprãns et al. [128] reported an increase of $\beta$-very low-density lipoprotein ( $\beta$-VLDL) fraction and the formation of fatty streak lesions in aortas in male New Zealand White rabbits fed a low-cholesterol $(0.25 \%)$ diet containing $5 \%$ thermal-oxidized corn oil. Atherosclerotic lesions have also been observed in genetically modified murine models, that is, $\mathrm{LDLR}^{-/-}$and apoE $\mathrm{E}^{-/-}$mice after chronic consumption of an oxidized cholesterol diet [129].

However, there are still limitations in the experimental animals used in the aforementioned studies. For instance, cholesterol diets in rabbits may lead to hepatic toxicity [96]. Furthermore, genetically modified mice are rather costly and may impose a substantial financial constraint to a research as well as limit the number of samples. Therefore, a more feasible and affordable alternative has been developed to induce atherosclerosis in rats. Adult female Sprague-Dawley rats were ovariectomized prior to 16 -week administration of $2 \%$ cholesterol diet fortified with $15 \% \mathrm{w} / \mathrm{w}$ of heated vegetable oil [130-132]. Ovariectomy was performed to simulate a postmenopausal condition characterized by the absence of cardioprotective estrogen [133].

Although there was a trend of increasing total cholesterol (TC) in all oil-fed groups, only heated oil-treated rats showed 
significant increase in serum TC compared to the control $[130,131]$. There were pronounced focal disruptions in the aortic intimal layer of the rats fed heated oil. Moreover, mononuclear cells were also observed in the intimal layer [132]. Based on the findings, it is possible to overwhelm rats' natural resistance to atherosclerosis by removing the ovaries. A further attempt was made to induce atherosclerosis in male Sprague-Dawley rats, as the use of the previous ovariectomized models is confined to menopause-induced atherosclerosis. Rats fed with standard rat chow fortified with $15 \%$ w/w of heated oil for 16 to 24 weeks. Histological study of the heart revealed cardiac toxicity with the presence of necrosis in cardiac tissue [52]. The intimal layer was observed to be noticeably thickened due to a massive lipid accumulation in the subendothelial space [134]. Lectinlike oxidized low-density lipoprotein receptor-1 (LOX-1), an endothelial receptor for endocytosis of oxLDL, was significantly increased in heated oil-fed rats compared to the control [135]. There were significant positive correlations between LOX-1 and the expressions of vascular cell adhesion molecule-1 (VCAM-1) and intercellular adhesion molecule-1 (ICAM-1) in heated oil-fed rats [135]. We suggest that heated oil diet can be used to induce atherosclerosis in rat models. However, the atherosclerosis-inducing effect seems to be more prominent in the ovariectomized rats than in male rats, as a longer period of intervention is required in male animals. Though the male rat model requires a longer duration of diet treatment to develop atherosclerosis, it is free from any surgical intervention in contrast to female rats undergoing ovariectomy. The use of other interventions such as vitamin $\mathrm{D}_{3}$ [123] may be helpful in the escalation of atherosclerotic plaque formation.

\section{Conclusion}

Progress in cardiovascular disease control requires understanding of the pathogenesis of the disease and testing of potential therapies, both experimentally and clinically. Experimental animal models, particularly murine species, have been a useful tool in this regard. The ideal animal model of cardiovascular disease should be representative to human conditions metabolically and pathophysiologically. The development of genetically modified animal models has enabled researchers to manipulate a specific target (either gene or protein), the role of which in pathogenesis may be subsequently established. This has led to the discovery of a vast spectrum of potential targets for ameliorative intervention. While the use of animal models has undeniably offered novel insights into different important aspects of a disease, still there are no species which are absolutely suitable for all studies, given the multifactorial nature of cardiovascular disease. Therefore, it is of utmost importance to choose an appropriate model to study different parts of cardiovascular disease. Otherwise, many exciting research findings may fail when translating into human studies. An agreement on appropriate experimental models for the study of different facades of cardiovascular disease would be a viable and effective strategy to further the advancement in this field.

\section{Conflict of Interests}

The authors declare no conflict of interests regarding publication of this paper.

\section{References}

[1] https://www.gov.uk/government/statistics/statistics-of-scientific-procedures-on-living-animals-great-britain-2013.

[2] T. B. Franklin, H. Russig, I. C. Weiss et al., "Epigenetic transmission of the impact of early stress across generations," Biological Psychiatry, vol. 68, no. 5, pp. 408-415, 2010.

[3] Z. T. Erickson, E. A. Falkenberg, and G. A. S. Metz, "Lifespan psychomotor behaviour profiles of multigenerational prenatal stress and artificial food dye effects in rats," PLoS ONE, vol. 9, no. 6, Article ID e92132, 2014.

[4] The Chimpanzee Sequencing and Analysis Consortium, "Initial sequence of the chimpanzee genome and comparison with the human genome," Nature, vol. 437, no. 7055, pp. 69-87, 2005.

[5] R. J. Mural, M. D. Adams, E. W. Myers et al., "A comparison of whole-genome shotgun-derived mouse chromosome 16 and the human genome," Science, vol. 296, no. 5573, pp. 1661-1671, 2004.

[6] B. G. Katzung, S. Masters, and A. Trevor, Basic and Clinical Pharmacology, Appleton \& Lange, Norwalk, Conn, USA, 12th edition, 2012.

[7] W. M. S. Russell and R. L. Burch, The Principles of Humane Experimental Technique, London, UK, Methuen, 1959, http:// altweb.jhsph.edu/pubs/books/humane_exp/het-toc\#.

[8] M. Emerson, "Refinement, reduction and replacement approaches to in vivo cardiovascular research," British Journal of Pharmacology, vol. 161, no. 4, pp. 749-754, 2010.

[9] C. Kilkenny, W. Browne, I. C. Cuthill, M. Emerson, and D. G. Altman, "Animal research: reporting in vivo experiments: the ARRIVE guidelines," British Journal of Pharmacology, vol. 160, no. 7, pp. 1577-1579, 2010.

[10] C. R. Hooijmans, M. Leenaars, and M. Ritskes-Hoitinga, "A gold standard publication checklist to improve the quality of animal studies, to fully integrate the three Rs, and to make systematic reviews more feasible," Alternatives to Laboratory Animals, vol. 38, no. 2, pp. 167-182, 2010.

[11] S. M. Williams, J. L. Haines, and J. H. Moore, "The use of animal models in the study of complex disease: all else is never equal or why do so many human studies fail to replicate animal findings?" BioEssays, vol. 26, no. 2, pp. 170-179, 2004.

[12] H. B. van der Worp, D. W. Howells, E. S. Sena et al., "Can animal models of disease reliably inform human studies?" PLoS Medicine, vol. 7, no. 3, Article ID e1000245, 2010.

[13] R. Greek and A. Menache, "Systematic reviews of animal models: methodology versus epistemology," International Journal of Medical Sciences, vol. 10, no. 3, pp. 206-221, 2013.

[14] J. Hau, "Animal models for human diseases," in Sourcebook of Models for Biomedical Research, P. M. Conn, Ed., pp. 3-8, Humana Press, Totowa, NJ, USA, 2008.

[15] M. B. Bracken, "Why animal studies are often poor predictors of human reactions to exposure," Journal of the Royal Society of Medicine, vol. 102, no. 3, pp. 120-122, 2009.

[16] L. E. Mignini and K. S. Khan, "Methodological quality of systematic reviews of animal studies: a survey of reviews of basic research," BMC Medical Research Methodology, vol. 6, article 10, 2006. 
[17] E. S. Sena, C. L. Briscoe, D. W. Howells, G. A. Donnan, P. A. G. Sandercock, and M. R. MacLeod, "Factors affecting the apparent efficacy and safety of tissue plasminogen activator in thrombotic occlusion models of stroke: systematic review and meta-analysis," Journal of Cerebral Blood Flow \& Metabolism, vol. 30, no. 12, pp. 1905-1913, 2010.

[18] C. R. Hooijmans and M. Ritskes-Hoitinga, "Progress in using systematic reviews of animal studies to improve translational research," PLoS Medicine, vol. 10, no. 7, Article ID e1001482, 2013.

[19] S. Yadav, R. Boddula, G. Genitta et al., "Prevalence \& risk factors of pre-hypertension \& hypertension in an affluent north Indian population," Indian Journal of Medical Research, vol. 128, no. 6, pp. 712-720, 2008.

[20] G. Danaei, E. L. Ding, D. Mozaffarian et al., "The preventable causes of death in the United States: comparative risk assessment of dietary, lifestyle, and metabolic risk factors," PLoS Medicine, vol. 6, no. 4, Article ID e1000058, 2009.

[21] World Health Organization, Global Health Risks: Mortality and Burden of Disease Attributable to Selected Major Risks, World Health Organization, Geneva, Switzerland, 2009.

[22] A. V. Chobanian, G. L. Bakris, H. R. Black et al., "The seventh report of the joint national committee on prevention, detection, evaluation, and treatment of high blood pressure: the JNC 7 report," The Journal of the American Medical Association, vol. 289, no. 19, pp. 2560-2572, 2003.

[23] S. A. Doggrell and L. Brown, "Rat models of hypertension, cardiac hypertrophy and failure," Cardiovascular Research, vol. 39, no. 1, pp. 89-105, 1998.

[24] D. K. Badyal, H. Lata, and A. P. Dadhich, "Animal models of hypertension and effect of drugs," Indian Journal of Pharmacology, vol. 35, no. 6, pp. 349-362, 2003.

[25] W. C. Dornas and M. E. Silva, "Animal models for the study of arterial hypertension," Journal of Biosciences, vol. 36, no. 4, pp. 731-737, 2011.

[26] W. Wang, R. Liu, G. Cao et al., "A reliable rabbit model for hyperkinetic pulmonary hypertension," The Journal of Thoracic and Cardiovascular Surgery, vol. 140, no. 2, pp. 395-399, 2010.

[27] F. Gross, "Experimental models of hypertension and their use in the evaluation of antihypertensive drugs," in Arterial Hypertension: The Gestation and Birth of a WHO Expert Committee Report, F. Gross and J. I. S. Robertson, Eds., pp. 198-208, G.K. Hall Medical Publishers, Boston, Mass, USA, 1980.

[28] K. Okamoto and K. Aoki, "Development of a strain of spontaneously hypertensive rats," Japanese Circulation Journal, vol. 27, no. 3, pp. 282-293, 1963.

[29] N. C. Trippodo and E. D. Frohlich, "Similarities of genetic (spontaneous) hypertension: man and rat," Circulation Research, vol. 48, no. 3, pp. 309-319, 1981.

[30] F. H. Smirk and W. H. Hall, "Inherited hypertension in rats," Nature, vol. 182, no. 4637, pp. 727-728, 1958.

[31] G. Bianchi, U. Fox, and E. Imbasciati, "The development of a new strain of spontaneously hypertensive rats," Life Sciences, vol. 14, no. 2, pp. 339-347, 1974.

[32] L. K. Dahl, M. Heine, and L. Tassinari, "Role of genetic factors in susceptibility to experimental hypertension due to chronic excess salt ingestion," Nature, vol. 194, no. 4827, pp. 480-482, 1962.

[33] N. Zamir, Y. Gutman, and D. Ben-Ishay, "Hypertension and brain catecholamine distribution in the Hebrew University Sabra, $\mathrm{H}$ and $\mathrm{N}$ rats," Clinical Science and Molecular Medicine, vol. 5, Supplement 5, 1978.
[34] M. Vincent, H. Bornet, F. Berthezene, J. Dupont, and J. Sassard, "Thyroid function and blood pressure in two new strains of spontaneously hypertensive and normotensive rats," Clinical Science and Molecular Medicine, vol. 54, no. 4, pp. 391-395, 1978.

[35] Y. M. Pinto, M. Paul, and D. Ganten, "Lessons from rat models of hypertension: from Goldblatt to genetic engineering," Cardiovascular Research, vol. 39, no. 1, pp. 77-88, 1998.

[36] Z.-J. Sun and Z.-E. Zhang, "Historic perspectives and recent advances in major animal models of hypertension," Acta Pharmacologica Sinica, vol. 26, no. 3, pp. 295-301, 2005.

[37] C. Fanelli and R. Zatz, "Linking oxidative stress, the reninangiotensin system, and hypertension," Hypertension, vol. 57, no. 3, pp. 373-374, 2011.

[38] H. Goldblatt, J. Lynch, R. F. Hanzal, and W. W. Summerville, "The production of persistent elevation of systolic blood pressure by means of renal ischemia," Journal of Experimental Medicine, vol. 59, no. 3, pp. 347-379, 1934.

[39] P. Zandberg, "Animal models in experimental hypertension: relevance to drug testing and discovery," in Pharmacology of Antihypertensive Drugs, P. A. van Zwieten, Ed., vol. 3 of Handbook of Hypertension, Elsevier Science, New York, NY, USA, 1984.

[40] T. Sawamura and T. Nakada, "Role of dopamine in the striatum, renin-angiotensin system and renal sympathetic nerve on the development of two-kidney, one-clip goldblatt hypertension," The Journal of Urology, vol. 155, no. 3, pp. 1108-1111, 1996.

[41] J. M. Flack, S. A. Atlas, J. L. Pool, and W. B. White, "Reninangiotensin aldosterone system and hypertension: current approaches and future directions," Journal of Managed Care Pharmacy, vol. 13, no. 8, supplement, pp. S2-S32, 2007.

[42] S. Moncada and A. Higgs, "The L-arginine-nitric oxide pathway," The New England Journal of Medicine, vol. 329, no. 27, pp. 2002-2012, 1993.

[43] R. F. Furchgott and P. M. Vanhoutte, "Endothelium-derived relaxing and contracting factors," The FASEB Journal, vol. 3, no. 9, pp. 2007-2018, 1989.

[44] M. Hermann, A. Flammer, and T. F. Lüscher, "Nitric oxide in hypertension," Journal of Clinical Hypertension, vol. 8, no. 12, supplement 4, pp. 17-29, 2006.

[45] R. Rahimian, G. P. Dubé, W. Toma, N. Dos Santos, B. M. McManus, and C. van Breemen, "Raloxifene enhances nitric oxide release in rat aorta via increasing endothelial nitric oxide mRNA expression," European Journal of Pharmacology, vol. 434, no. 3, pp. 141-149, 2002.

[46] J.-C. Zhong, X.-Y. Yu, Y. Huang, L.-M. Yung, C.-W. Lau, and S.G. Lin, "Apelin modulates aortic vascular tone via endothelial nitric oxide synthase phosphorylation pathway in diabetic mice," Cardiovascular Research, vol. 74, no. 3, pp. 388-395, 2007.

[47] V. Ramanathan and M. Thekkumalai, "Role of chrysin on hepatic and renal activities of $\mathrm{N}^{\omega}$-nitro-L-arginine-methlyester induced hypertensive rats," International Journal of Nutrition, Pharmacology and Neurological Diseases, vol. 4, no. 1, pp. 5863, 2014.

[48] C. F. Kung, P. Moreau, H. Takase, and T. F. Luscher, "LNAME hypertension alters endothelial and smooth muscle function in rat aorta: Prevention by trandolapril and verapamil," Hypertension, vol. 26, no. 5, pp. 744-751, 1995.

[49] H. François, S. Placier, M. Flamant et al., "Prevention of renal vascular and glomerular fibrosis by epidermal growth factor receptor inhibition," The FASEB Journal, vol. 18, no. 7, pp. 926928, 2004. 
[50] P. Nyadjeu, E. P. Nguelefack-Mbuyo, A. D. Atsamo, T. B. Nguelefack, A. B. Dongmo, and A. Kamanyi, "Acute and chronic antihypertensive effects of Cinnamomum zeylanicum stem bark methanol extract in L-NAME-induced hypertensive rats," $B M C$ Complementary and Alternative Medicine, vol. 13, article 27, 2013.

[51] F. Soriguer, G. Rojo-Martínez, M. C. Dobarganes et al., "Hypertension is related to the degradation of dietary frying oils," The American Journal of Clinical Nutrition, vol. 78, no. 6, pp. 10921097, 2003.

[52] X. F. Leong, A. Aishah, U. Nor Aini, S. Das, and K. Jaarin, "Heated palm oil causes rise in blood pressure and cardiac changes in heart muscle in experimental rats," Archives of Medical Research, vol. 39, no. 6, pp. 567-572, 2008.

[53] X.-F. Leong, M. N. M. Najib, S. Das, M. R. Mustafa, and K. Jaarin, "Intake of repeatedly heated palm oil causes elevation in blood pressure with impaired vasorelaxation in rats," The Tohoku Journal of Experimental Medicine, vol. 219, no. 1, pp. 7178, 2009.

[54] X.-F. Leong, M. R. Mustafa, S. Das, and K. Jaarin, "Association of elevated blood pressure and impaired vasorelaxation in experimental Sprague-Dawley rats fed with heated vegetable oil," Lipids in Health and Disease, vol. 9, article 66, 2010.

[55] K. Jaarin, M. R. Mustafa, and X.-F. Leong, "The effects of heated vegetable oils on blood pressure in rats," Clinics, vol. 66, no. 12, pp. 2125-2132, 2011.

[56] X.-F. Leong, J. Salimon, M. R. Mustafa, and K. Jaarin, "Effect of repeatedly heated palm olein on blood pressure-regulating enzymes activity and lipid peroxidation in rats," Malaysian Journal of Medical Sciences, vol. 19, no. 1, pp. 20-29, 2012.

[57] J. D. Gardner, G. L. Brower, T. G. Voloshenyuk, and J. S. Janicki, "Cardioprotection in female rats subjected to chronic volume overload: synergistic interaction of estrogen and phytoestrogens," American Journal of Physiology: Heart and Circulatory Physiology, vol. 294, no. 1, pp. H198-H204, 2008.

[58] C. Campos, C. L. Sartorio, K. R. Casali et al., "Low-dose estrogen is as effective as high-dose treatment in rats with postmenopausal hypertension," Journal of Cardiovascular Pharmacology, vol. 63, no. 2, pp. 144-151, 2014.

[59] J. H. Krege, J. B. Hodgin, J. R. Hagaman, and O. Smithies, "A noninvasive computerized tail-cuff system for measuring blood pressure in mice," Hypertension, vol. 25, no. 5, pp. 1111-1115, 1995.

[60] L. Yan, J. D. Zhang, B. Wang et al., "Quercetin inhibits left ventricular hypertrophy in spontaneously hypertensive rats and inhibits angiotensin II-induced H9C2 c ells hypertrophy by enhancing PPAR- $\gamma$ expression and suppressing AP-1 activity," PLoS ONE, vol. 8, no. 9, Article ID e72548, 2013.

[61] W. J. Welch, H. Baumgärtl, D. Lübbers, and C. S. Wilcox, "Renal oxygenation defects in the spontaneously hypertensive rat: role of AT1 receptors," Kidney International, vol. 63, no. 1, pp. 202208, 2003.

[62] C. S. Packer, "Changes in arterial smooth muscle contractility, contractile proteins, and arterial wall structure in spontaneous hypertension," Proceedings of the Society for Experimental Biology and Medicine, vol. 207, no. 2, pp. 148-174, 1994.

[63] S. Klotz, I. Hay, G. Zhang, M. Maurer, J. Wang, and D. Burkhoff, "Development of heart failure in chronic hypertensive Dahl rats: focus on heart failure with preserved ejection fraction," Hypertension, vol. 47, no. 5, pp. 901-911, 2006.

[64] N. Tian, R. A. Rose, S. Jordan, T. M. Dwyer, M. D. Hughson, and R. D. Manning Jr., "N-Acetylcysteine improves renal dysfunction, ameliorates kidney damage and decreases blood pressure in salt-sensitive hypertension," Journal of Hypertension, vol. 24, no. 11, pp. 2263-2270, 2006.

[65] Y.-N. Cao, K. Kuwasako, J. Kato et al., "Beyond vasodilation: the antioxidant effect of adrenomedullin in Dahl salt-sensitive rat aorta," Biochemical and Biophysical Research Communications, vol. 332, no. 3, pp. 866-872, 2005.

[66] J. J. Mullins, J. Peters, and D. Ganten, "Fulminant hypertension in transgenic rats harbouring the mouse Ren-2 gene," Nature, vol. 344 , no. 6266, pp. 541-544, 1990.

[67] O. Chung, T. Schips, P. Rohmeiss, N. Gretz, M. Strauch, and T. Unger, "Protein excretion and renal adaptation of transgenic mRen2 rats to changing oral sodium loads," Journal of Hypertension, vol. 11, no. 5, pp. S188-S189, 1993.

[68] Y. M. Pinto, H. Buikema, W. H. van Gilst et al., "Cardiovascular end-organ damage in Ren-2 transgenic rats compared to spontaneously hypertensive rats," Journal of Molecular Medicine, vol. 75, no. 5, pp. 371-377, 1997.

[69] H. Selye, C. E. Hall, and E. M. Rowley, "Malignant hypertension produced by treatment with deoxycorticosterone acetate and sodium chloride," Canadian Medical Association Journal, vol. 49, no. 2, pp. 88-92, 1943.

[70] V. Chamorro, R. Wangensteen, J. Sainz et al., "Protective effects of the angiotensin II type I (AT1) receptor blockade in low-renin deoxycorticosterone acetate (DOCA)-treated spontaneously hypertensive rats," Clinical Science, vol. 106, no. 3, pp. 251-259, 2004.

[71] A. Iyer, V. Chan, and L. Brown, "The DOCA-salt hypertensive rat as a model of cardiovascular oxidative and inflammatory stress," Current Cardiology Reviews, vol. 6, no. 4, pp. 291-297, 2010.

[72] B. Klanke, N. Cordasic, A. Hartner, R. E. Schmieder, R. Veelken, and K. F. Hilgers, "Blood pressure versus direct mineralocorticoid effects on kidney inflammation and fibrosis in DOCA-salt hypertension," Nephrology Dialysis Transplantation, vol. 23, no. 11, pp. 3456-3463, 2008.

[73] J. P. Henry, Y.-Y. Liu, W. E. Nadra et al., "Psychosocial stress can induce chronic hypertension in normotensive strains of rats," Hypertension, vol. 21, no. 5, pp. 714-723, 1993.

[74] A. G. Bechtold, G. Patel, G. Hochhaus, and D. A. Scheuer, "Chronic blockade of hindbrain glucocorticoid receptors reduces blood pressure responses to novel stress and attenuates adaptation to repeated stress," The American Journal of Physiology-Regulatory Integrative and Comparative Physiology, vol. 296, no. 5, pp. R1445-R1454, 2009.

[75] P. A. Smith, L. N. Graham, A. F. Mackintosh, J. B. Stoker, and D. A. S. G. Mary, "Sympathetic neural mechanisms in white-coat hypertension," Journal of the American College of Cardiology, vol. 40, no. 1, pp. 126-132, 2002.

[76] S. C. Coste, V. L. Brooks, D. A. McCarron, D. C. Hatton, and Y. Qi, "Captopril and stress-induced hypertension in the borderline hypertensive rat," Journal of Hypertension, vol. 13, no. 12, pp. 1391-1398, 1995.

[77] Y. Nishijima, X. Zheng, H. Lund, M. Suzuki, D. L. Mattson, and D. X. Zhang, "Characterization of blood pressure and endothelial function in TRPV4-deficient mice with L-NAME- and angiotensin II-induced hypertension," Physiological Reports, vol. 2, Article ID e00199, 2014.

[78] F. Xavier, A. M. F. Magalhães, and J. A. R. Gontijo, "Effect of inhibition of nitric oxide synthase on blood pressure and renal sodium handling in renal denervated rats," Brazilian Journal of Medical and Biological Research, vol. 33, no. 3, pp. 347-354, 2000 . 
[79] H. Rauchová, O. Pecháňová, J. Kuneš, M. Vokurková, Z. Dobešová, and J. Zicha, "Chronic $N$-acetylcysteine administration prevents development of hypertension in $H^{\omega}$-nitro-Larginine methyl ester-treated rats: the role of reactive oxygen species," Hypertension Research, vol. 28, no. 5, pp. 475-482, 2005.

[80] I. Bernatova, "Endothelial dysfunction in experimental models of arterial hypertension: cause or consequence?" BioMed Research International, vol. 2014, Article ID 598271, 14 pages, 2014.

[81] P. Wiesel, L. Mazzolai, J. Nussberger, and T. Pedrazzini, “Twokidney, one clip and one-kidney, one clip hypertension in mice," Hypertension, vol. 29, no. 4, pp. 1025-1030, 1997.

[82] J. Zeng, Y. Zhang, J. Mo, Z. Su, and R. Huang, "Two-kidney, two clip renovascular hypertensive rats can be used as stroke-prone rats," Stroke, vol. 29, no. 8, pp. 1708-1714, 1998.

[83] H. Kiyomoto, H. Kobori, and A. Nishiyama, "Renin-angiotensin system in the kidney and oxidative stress: local renin-angiotensin-aldosterone system and NADPH oxidasedependent oxidative stress in the kidney," in Studies on Renal Disorders, Oxidative Stress in Applied Basic Research and Clinical Practice, T. Miyata, K.-U. Eckardt, and M. Nangaku, Eds., pp. 71-91, Springer Science, Boston, Mass, USA, 2011.

[84] J. Y. Moon, "Recent update of renin-angiotensin-aldosterone system in the pathogenesis of hypertension," Electrolytes \& Blood Pressure, vol. 11, no. 2, pp. 41-45, 2013.

[85] World Health Organization, Global Atlas on Cardiovascular Disease Prevention and Control, World Health Organization, Geneva, Switzerland, 2011.

[86] G. Douglas and K. M. Channon, "The pathogenesis of atherosclerosis," Medicine, vol. 38, no. 8, pp. 397-402, 2010.

[87] A. C. Ignatowski, "Influence of animal food on the organism of rabbits," Izvestia Imperatorskoi Voenno-Medicinskoi Akademii (St Petersburg), vol. 16, pp. 154-176, 1908.

[88] H. Beaufrère, "Atherosclerosis: comparative pathogenesis, lipoprotein metabolism, and Avian and exotic companion mammal models," Journal of Exotic Pet Medicine, vol. 22, no. 4, pp. 320-335, 2013.

[89] F. R. Kapourchali, G. Surendiran, L. Chen, E. Uitz, B. Bahadori, and M. H. Moghadasian, "Animal models of atherosclerosis," World Journal of Clinical Cases, vol. 2, no. 5, pp. 126-132, 2014.

[90] P. F. Bodary and D. T. Eitzman, "Animal models of thrombosis," Current Opinion in Hematology, vol. 16, no. 5, pp. 342-346, 2009.

[91] T.-F. Tzeng, H.-J. Lu, S.-S. Liou, C. J. Chang, and I.-M. Liu, "Lipid-lowering effects of zerumbone, a natural cyclic sesquiterpene of Zingiber zerumbet Smith, in high-fat diet-induced hyperlipidemic hamsters," Food and Chemical Toxicology, vol. 69, pp. 132-139, 2014.

[92] M. C. Podszun, N. Grebenstein, A. Spruss et al., "Dietary $\alpha$-tocopherol and atorvastatin reduce high-fat-induced lipid accumulation and down-regulate CD36 protein in the liver of guinea pigs," The Journal of Nutritional Biochemistry, vol. 25, no. 5, pp. 573-579, 2014.

[93] Y. C. Haa and P. J. Barter, "Differences in plasma cholesteryl ester transfer activity in sixteen vertebrate species," Comparative Biochemistry and Physiology - Part B: Biochemistry \& Molecular Biology, vol. 71, no. 2, pp. 265-269, 1982.

[94] S. H. Quarfordt, B. Landis, G. Cucchiaro, Y. Yamaguchi, and B. Oswald, "Plasma cholesterol transport in anhepatic rats," Journal of Clinical Investigation, vol. 89, no. 5, pp. 1564-1570, 1992.
[95] M. H. Moghadasian, J. J. Frohlich, and B. M. McManus, "Advances in experimental dyslipidemia and atherosclerosis," Laboratory Investigation, vol. 81, no. 9, pp. 1173-1183, 2001.

[96] A. E. Yanni, "The laboratory rabbit: an animal model of atherosclerosis research," Laboratory Animals, vol. 38, no. 3, pp. 246-256, 2004.

[97] T. Gardner and D. Johnson, "Cardiovascular system," in Experimental Surgery and Physiology: Induced Animal Models of Human Disease, M. M. Swindle and R. J. Adams, Eds., pp. 74-124, Lippincott Williams \& Wilkins, Philadelphia, Pa, USA, 1988.

[98] V. Fuster, J. T. Lie, L. Badimon, J. A. Rosemark, and E. J. Bowie, "Spontaneous and diet-induced coronary atherosclerosis in normal swine and swine with von Willebrand disease," Arteriosclerosis, vol. 5, no. 1, pp. 67-73, 1985.

[99] F. C. White, S. M. Carroll, A. Magnet, and C. M. Bloor, "Coronary collateral development in swine after coronary artery occlusion," Circulation Research, vol. 71, no. 6, pp. 1490-1500, 1992.

[100] G. Kemming, J. B. Messick, W. Mueller et al., "Can we continue research in splenectomized dogs? Mycoplasma haemocanis: old problem-new insight," European Surgical Research, vol. 36, no. 4, pp. 198-205, 2004.

[101] A. L. Lock, C. A. M. Horne, D. E. Bauman, and A. M. Salter, "Butter naturally enriched in conjugated linoleic acid and vaccenic acid alters tissue fatty acids and improves the plasma lipoprotein profile in cholesterol-fed hamsters," Journal of Nutrition, vol. 135, no. 8, pp. 1934-1939, 2005.

[102] S. E. Dorfman, S. Wang, S. Vega-López, M. Jauhiainen, and A. H. Lichtenstein, "Dietary fatty acids and cholesterol differentially modulate HDL cholesterol metabolism in Golden-Syrian hamsters," Journal of Nutrition, vol. 135, no. 3, pp. 492-498, 2005.

[103] A. Dillard, N. R. Matthan, and A. H. Lichtenstein, "Use of hamster as a model to study diet-induced atherosclerosis," Nutrition \& Metabolism, vol. 7, article 89, 2010.

[104] J. C. Russell and S. D. Proctor, "Small animal models of cardiovascular disease: tools for the study of the roles of metabolic syndrome, dyslipidemia, and atherosclerosis," Cardiovascular Pathology, vol. 15, no. 6, pp. 318-330, 2006.

[105] M. L. Fernandez and D. J. McNamar, "Dietary fat-mediated changes in hepatic apoprotein $\mathrm{B} / \mathrm{E}$ receptor in the guinea pig: effect of polyunsaturated, monounsaturated, and saturated fat," Metabolism, vol. 38, no. 11, pp. 1094-1102, 1989.

[106] T. L. Zern, K. L. West, and M. L. Fernandez, "Grape polyphenols decrease plasma triglycerides and cholesterol accumulation in the aorta of ovariectomized guinea pigs," Journal of Nutrition, vol. 133, no. 7, pp. 2268-2272, 2003.

[107] M. L. Fernandez and J. S. Volek, “Guinea pigs: a suitable animal model to study lipoprotein metabolism, atherosclerosis and inflammation," Nutrition and Metabolism, vol. 3, article 17, 2006.

[108] B. C. Hansen and N. L. Bodkin, "Primary prevention of diabetes mellitus by prevention of obesity in monkeys," Diabetes, vol. 42, no. 12, pp. 1809-1814, 1993.

[109] H. A. Barakat and R. W. St. Clair, "Characterization of plasma lipoproteins of grain- and cholesterol-fed White Carneau and Show Racer pigeons," The Journal of Lipid Research, vol. 26, no. 10, pp. 1252-1268, 1985.

[110] L. C. Stout and L. W. Thorpe, "Histology of normal aortas in birds with emphasis on intimal thickening," Atherosclerosis, vol. 36, no. 4, pp. 545-558, 1980. 
[111] D. V. V. Dauber and L. N. N. Katz, "Experimental atherosclerosis in the chick," Archives of Pathology, vol. 36, no. 5, pp. 473-492, 1943.

[112] D. P. Hajjar, C. G. Fabricant, C. R. Minick, and J. Fabricant, "Virus-induced atherosclerosis. Herpesvirus infection alters aortic cholesterol metabolism and accumulation," The American Journal of Pathology, vol. 122, no. 1, pp. 62-70, 1986.

[113] C. G. Fabricant and J. Fabricant, "Atherosclerosis induced by infection with Marek's disease herpesvirus in chickens," The American Heart Journal, vol. 138, no. 5, part, pp. S465-S468, 1999.

[114] S. H. Zhang, R. L. Reddick, J. A. Piedrahita, and N. Maeda, "Spontaneous hypercholesterolemia and arterial lesions in mice lacking apolipoprotein E," Science, vol. 258, no. 5081, pp. 468471, 1992.

[115] S. Ishibashi, M. S. Brown, J. L. Goldstein, R. D. Gerard, R. E. Hammer, and J. Herz, "Hypercholesterolemia in low density lipoprotein receptor knockout mice and its reversal by adenovirus-mediated gene delivery," The Journal of Clinical Investigation, vol. 92, no. 2, pp. 883-893, 1993.

[116] A. Rigotti, B. L. Trigatti, M. Penman, H. Rayburn, J. Herz, and M. Krieger, "A targeted mutation in the murine gene encoding the high density lipoprotein (HDL) receptor scavenger receptor class B type I reveals its key role in HDL metabolism," Proceedings of the National Academy of Sciences of the United States of America, vol. 94, no. 23, pp. 12610-12615, 1997.

[117] J. Buchanan, P. K. Mazumder, P. Hu et al., "Reduced cardiac efficiency and altered substrate metabolism precedes the onset of hyperglycemia and contractile dysfunction in two mouse models of insulin resistance and obesity," Endocrinology, vol. 146, no. 12, pp. 5341-5349, 2005.

[118] B. Winters, Z. Mo, E. Brooks-Asplund et al., "Reduction of obesity, as induced by leptin, reverses endothelial dysfunction in obese $\left(L e p^{o b}\right)$ mice," Journal of Applied Physiology, vol. 89, no. 6, pp. 2382-2390, 2000.

[119] L. M. Zucker and H. N. Antoniades, "Insulin and obesity in the Zucker genetically obese rat "fatty"', Endocrinology, vol. 90, no. 5, pp. 1320-1330, 1972.

[120] Z. Zak, T. Gautier, L. Dumont et al., "Effect of cholesteryl ester transfer protein (CETP) expression on diet-induced hyperlipidemias in transgenic rats," Atherosclerosis, vol. 178, no. 2, pp. 279-286, 2005.

[121] P. J. Dolphin, "Serum and hepatic nascent lipoproteins in normal and hypercholesterolemic rats," Journal of Lipid Research, vol. 22, no. 6, pp. 971-989, 1981.

[122] X. Li, Y. Liu, H. Zhang, L. Ren, Q. Li, and N. Li, "Animal models for the atherosclerosis research: a review," Protein and Cell, vol. 2, no. 3, pp. 189-201, 2011.

[123] J. Pang, Q. Xu, X. Xu et al., "Hexarelin suppresses high lipid diet and vitamin D3-induced atherosclerosis in the rat," Peptides, vol. 31, no. 4, pp. 630-638, 2010.

[124] Y. Okada, K. Yamaguchi, T. Nakajima et al., "Rosuvastatin ameliorates high-fat and high-cholesterol diet-induced nonalcoholic steatohepatitis in rats," Liver International, vol. 33, no. 2, pp. 301-311, 2013.

[125] A. H. Lichtman, S. K. Clinton, K. Iiyama, P. W. Connelly, P. Libby, and M. I. Cybulsky, "Hyperlipidemia and atherosclerotic lesion development in LDL receptor-deficient mice fed defined semipurified diets with and without cholate," Arteriosclerosis, Thrombosis, and Vascular Biology, vol. 19, no. 8, pp. 1938-1944, 1999.
[126] M. T. Quinn, S. Parthasarathy, L. G. Fong, and D. Steinberg, "Oxidatively modified low density lipoproteins: a potential role in recruitment and retention of monocyte/macrophages during atherogenesis," Proceedings of the National Academy of Sciences of the United States of America, vol. 84, no. 9, pp. 2995-2998, 1987.

[127] S. R. J. Maxwell and G. Y. H. Lip, "Free radicals and antioxidants in cardiovascular disease," British Journal of Clinical Pharmacology, vol. 44, no. 4, pp. 307-317, 1997.

[128] I. Staprãns, J. H. Rapp, X.-M. Pan, D. A. Hardman, and K. R. Feingold, "Oxidized lipids in the diet accelerate the development of fatty streaks in cholesterol-fed rabbits," Arteriosclerosis, Thrombosis, and Vascular Biology, vol. 16, no. 4, pp. 533-538, 1996.

[129] I. Staprans, X.-M. Pan, J. H. Rapp, C. Grunfeld, and K. R. Feingold, "Oxidized cholesterol in the diet accelerates the development of atherosclerosis in LDL receptor- and apolipoprotein E-deficient mice," Arteriosclerosis, Thrombosis, and Vascular Biology, vol. 20, no. 3, pp. 708-714, 2000.

[130] S. K. Adam, S. Das, I. N. Soelaiman, N. A. Umar, and K. Jaarin, "Consumption of repeatedly heated soy oil increases the serum parameters related to atherosclerosis in Ovariectomized rats," The Tohoku Journal of Experimental Medicine, vol. 215, no. 3, pp. 219-226, 2008.

[131] S. K. Adam, I. N. Soelaiman, N. A. Umar, N. Mokhtar, N. Mohamed, and K. Jaarin, "Effects of repeatedly heated palm oil on serum lipid profile, lipid peroxidation and homocysteine levels in a post-menopausal rat model," McGill Journal of Medicine, vol. 11, no. 2, pp. 145-151, 2008.

[132] S. K. Adam, S. Das, and K. Jaarin, "A detailed microscopic study of the changes in the aorta of experimental model of postmenopausal rats fed with repeatedly heated palm oil," International Journal of Experimental Pathology, vol. 90, no. 3, pp. 321-327, 2009.

[133] W. B. Kannel and P. W. F. Wilson, "Risk factors that attenuate the female coronary disease advantage," Archives of Internal Medicine, vol. 155, no. 1, pp. 57-61, 1995.

[134] T. K. Xian, N. A. Omar, L. W. Ying et al., "Reheated palm oil consumption and risk of atherosclerosis: evidence at ultrastructural level," Evidence-Based Complementary and Alternative Medicine, vol. 2012, Article ID 828170, 6 pages, 2012.

[135] C.-Y. Ng, Y. Kamisah, O. Faizah, and K. Jaarin, "The role of repeatedly heated soybean oil in the development of hypertension in rats: association with vascular inflammation," International Journal of Experimental Pathology, vol. 93, no. 5, pp. 377$387,2012$. 


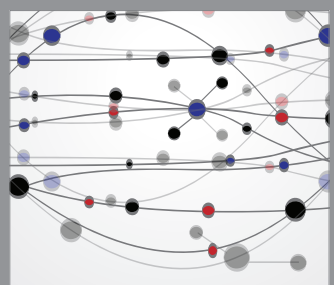

The Scientific World Journal
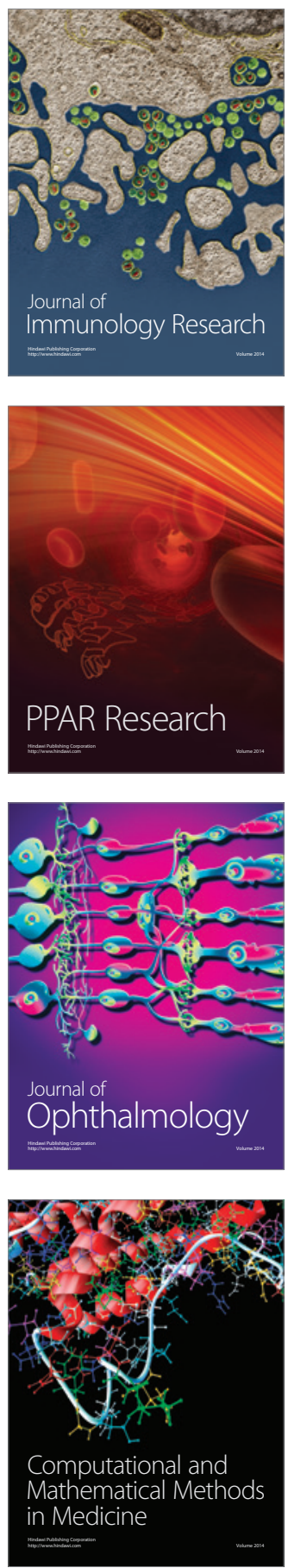

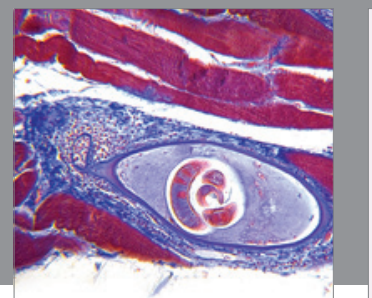

Gastroenterology

Research and Practice
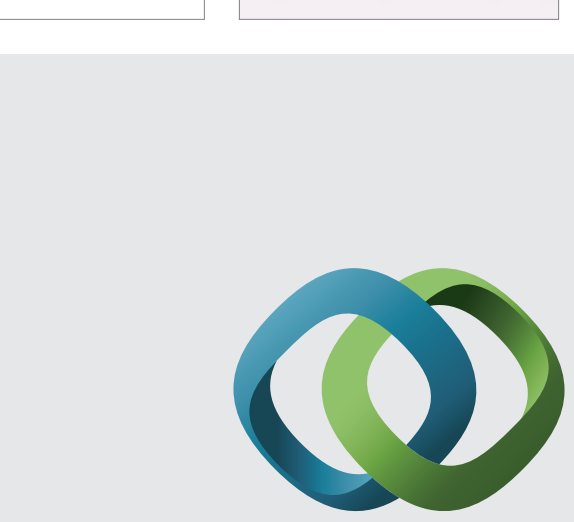

\section{Hindawi}

Submit your manuscripts at

http://www.hindawi.com
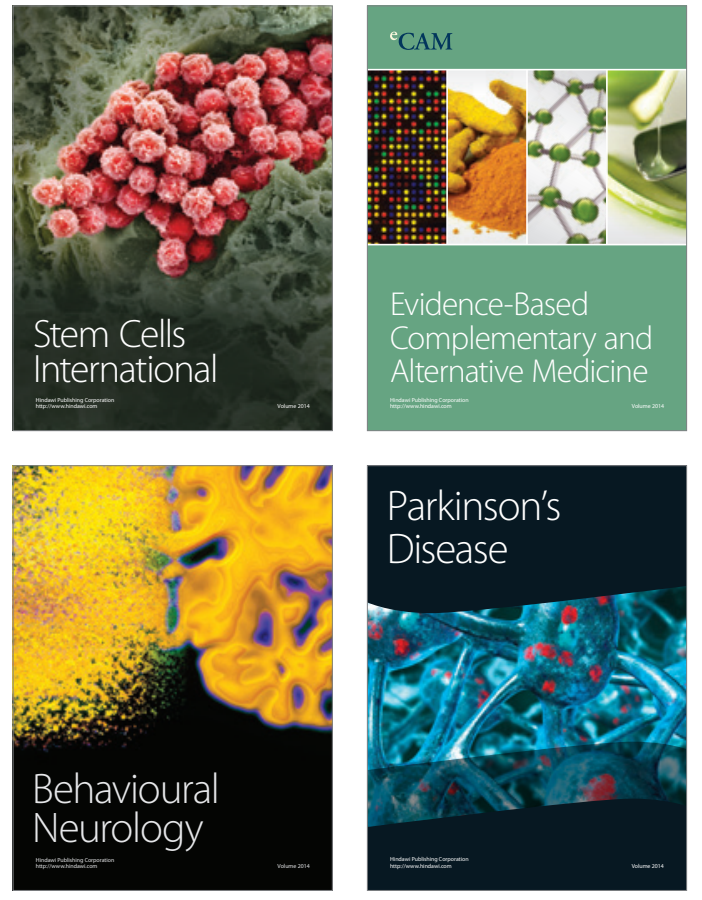
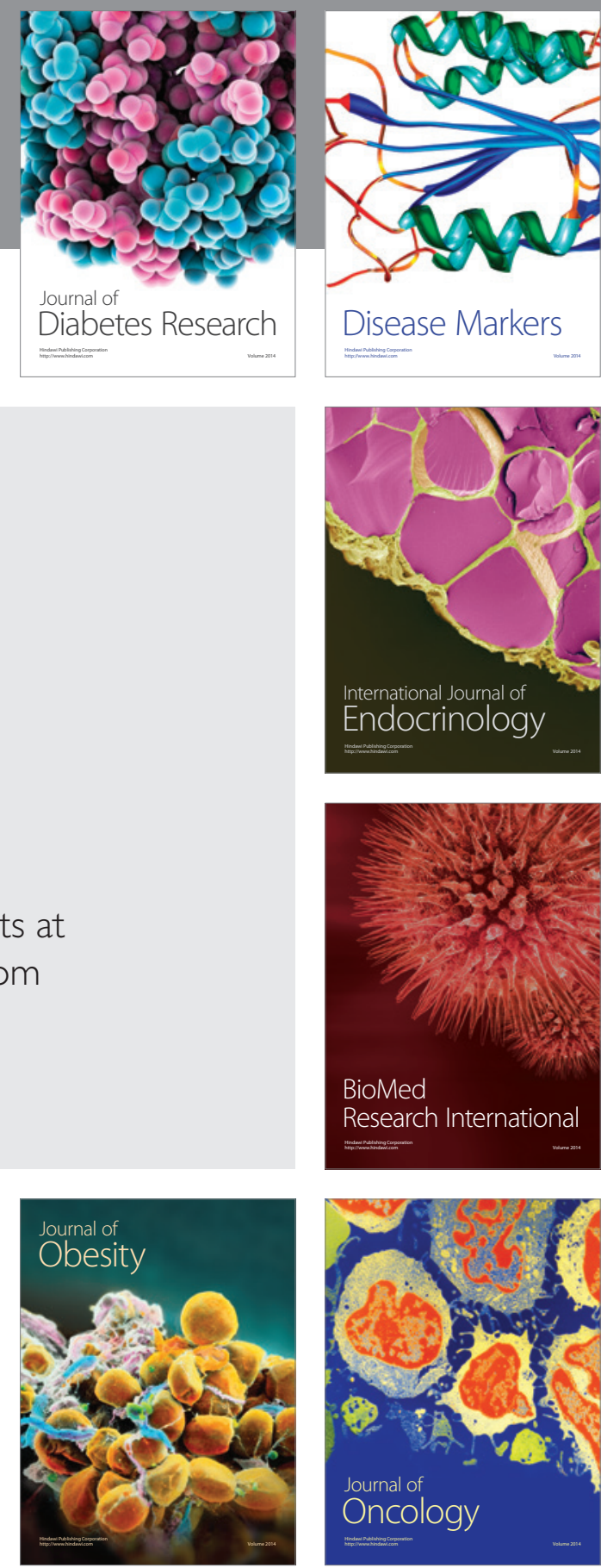

Disease Markers
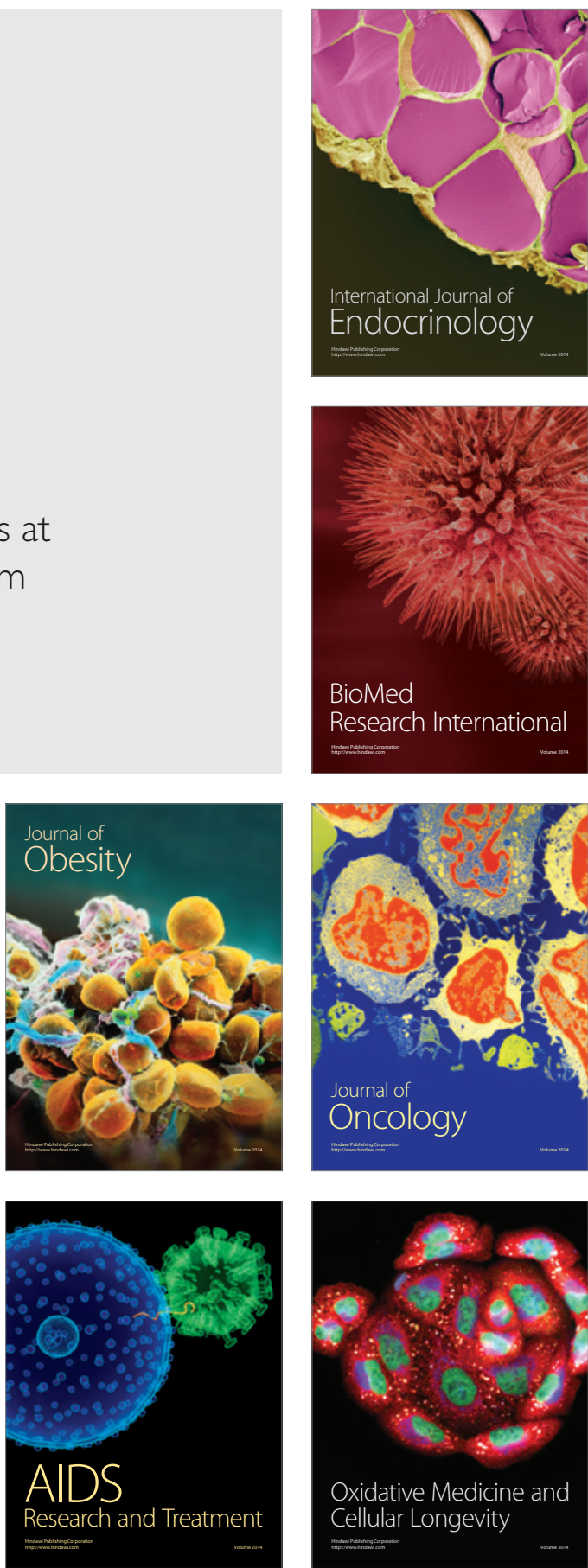